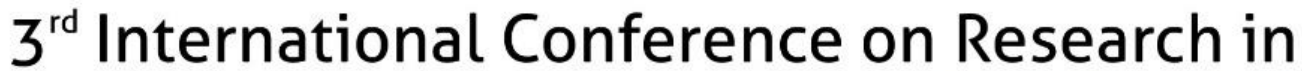 EDUCATION
}

\section{Chinese Language Teachers' stories of Teacher-student Relationships in a Multicultural Context}

\author{
Chan Rainbow Rung \\ The University of Hong Kong, Hong Kong
}

\begin{abstract}
.
Researches have identified the importance of teacher-student relationship building to students' learning motivation, academic achievement, and teachers' well-being. Looking into Hong Kong context, Chinese language teachers tried various ways to build affective relationships with their students with multi-cultural background to help them adopt life in Hong Kong and learn Chinese more effectively. The purpose of this study was to examine relationships with multi-cultural students at risk and to capture the view on teacher-child relationships by eliciting information from teachers through interviews. The research questions were conveyed from Rytivaara \& Frelin (2017) and amended with the context in Hong Kong to study: (1) How do the teachers narrate their relationships with their multi-cultural students? (2) How do the teachers narrate other adults regarding the multi-cultural students? (3) How do the teachers narrate change in their relationships with their multi-cultural students? Data for this study were drawn from 4 Non-Chinese speaking Students Development Officers from primary schools and secondary schools. Narrative analysis was applied to analyze the teachers' stories. It was found that positive teacher-student relationships shared the characteristics of peer relationship and family relationship, and the interaction with other stakeholders affected relationship building. In addition, the quality of teacher-student relationship will also affect the well-being and job satisfaction of teachers. Implications on teacher training and support network were reported in the findings. This research was expected to fill the research gap of researching teacher-student relationship with regard to the unique situation in Hong Kong with Chinese language teachers teaching multi-cultural students.
\end{abstract}

Keywords: narrative; second-language; at-risk; collaboration; affect

\section{Introduction}

Looking into the Hong Kong context, the Race Discrimination Ordinance has been enacted in Hong Kong over 10 years. Students with different ethnic background can enjoy the same educational service since the Ordinance enacted.

In order to participate in the life and achieve academic success at schools in Hong Kong, students with multi-cultural background must first deal with language problems (張慧明, 2018), and to develop fundamental skills in Chinese so that they can read the textbooks and comprehend explanations and instructions from the teachers(Valdés, 1998). Although Hong Kong is home to speakers of a variety of languages and dialect, Cantonese is now spoken by 


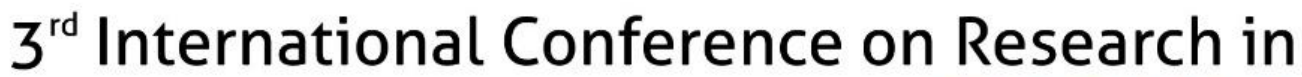 EDUCATION}

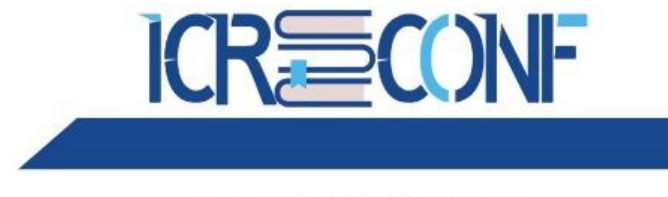

5-7 MARCH 2021 BERLIN, GERMANY

approximately $97 \%$ of the population (Morris \& Adamson, 2010). Furthermore, government schools in Hong Kong mainly use Chinese as the language of instruction. If multi-cultural students can adapt to the Chinese-based learning environment, they will broaden their choice of schools (香港課發展議會，2008).

Most of the ethnical minority students studying in government and subsidized schools are students in need with special care (祁永華, 2012). Due to cultural differences, adaptation to life in Hong Kong, difficulties in learning Chinese, and lack of motivation, conflicts exist among teachers and their multi-cultural students. In particular, teachers in charge of teaching Chinese need to help students learn by establishing good teachers and students.

Teacher-student relationships are of vital importance to teachers' daily work in the classrooms (Rytivaara \& Frelin, 2017). It affects students with their motivation, self-esteem that further influence student's subject performance (Wubbels \& Brekelmans, 2005; Baker, kGrant \& Morlock, 2008). A positive teacher-student relationship primarily benefits students who need special caring. Besides, it also influences teachers' well-being and sense of satisfaction with work.

Chinese language teachers are able to help students integrate into Hong Kong society and they are essential for building a good relationship with students. Improving students' Chinese proficiency will make it easier for them to adapt to Hong Kong society. It is the sole responsibility and advantage to build the relationship of Chinese teachers. In addition, Chinese lessons hours account for a large proportion of school education (香港課發展議會，2008), plus the additional language teaching time provided by the school especially for multi-cultural students, Chinese teachers have the most time to meet and communicate with these students, is conducive to the establishment of the teacher-student relationship. Meanwhile, the Chinese language curriculum includes positive moral values; Chinese teachers can use their academic advantages to have in-depth emotional communication with students. Therefore, Chinese teachers are better able to establish good relationships with students and bring changes to students through teaching languages.

This research explored the contradictions and tensions in teachers' stories about multi-cultural students with whom they have experienced challenging yet rewarding relationships and how the school and parents take part in relationship building.

\section{Body of paper}

\section{Introduction}

This study explored the challenging but rewarding teacher-student relationship between Chinese language teachers and their multi-cultural students who caused them troubles, made them laugh and guided them to reflect. This study was aimed at adding to the knowledge base by paying attention to the teachers' perspectives and their struggles while teaching Chinese language to multi-cultural students. 


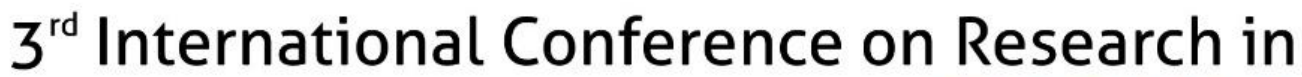 EDUCATION}

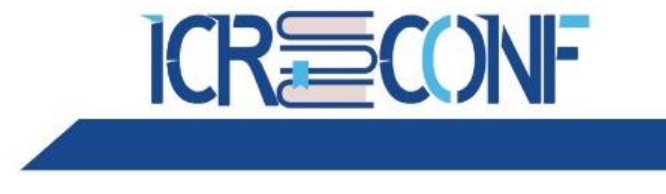

5-7 MARCH 2021 BERLIN, GERMANY

This study focused on relationships with students with multi-cultural background because children at risk were especially sensitive to the quality of teacher-child relationship (Split \& Koomen, 2009). It is aimed to capture the view on teacher-child relationships by eliciting information from teachers through interviews. The research questions were conveyed from Rytivaara \& Frelin (2017) and amended with the context in Hong Kong:

1. How do the teachers narrate their relationships with their multi-cultural students?

2. How do the teachers narrate other adults that regarding the multi-cultural students?

3. How do the teachers narrate change in their relationships with their multi-cultural students?

\section{Methods}

The goals of educational research is to report, explain, predict, control and apply to educational events to achieve the vision of improving the quality of education (葉重新 , 2012). These goals can be applied to this study in that the researcher aimed at describing the relationship between language teachers and their multi-cultural students.

The method used for this study was narrative inquiry (Connelly \& Clandinin, 1990). It is a process of collaboration of both the participants and the researcher. The participants tell their stories and the researcher retell them as the research proceeds (Webb \& Blond, 1995). In this research, narrative inquiry method helped to understand the teacher-student relationship between the participants and the students and explore the reasons for conflict and positive situations in the teacher-student relationship by the researcher.

\section{Participants}

The sample consisted 4 Chinese language teachers. They have been selected based on purposive sampling method. Purposive sampling is a deliberate choice of participants due to their quality (Etikan, Musa\& Alkassim, 2016). All participants are Non-Chinese speaking Students Development Officer (非華語學生統籌主任) of their schools. In addition to teaching Chinese to multi-cultural students, they are also responsible for coordinating the development of multi-cultural students in school, such as curriculum development and use of funding. All participants have bachelor degrees. The schools that participants are serving included both direct-subsidized schools and aided schools; primary schools and secondary schools. Only Teacher $\mathrm{C}$ received regular training about teaching multi-cultural students and the other participants only attended related seminars and workshops. One of the participants was male and three were female, and they were between 28-33 years old. The participants have taught multi-cultural students for 4-10 years. 


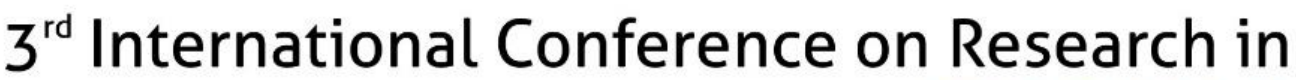 EDUCATION}

Table 1: Description of the participants

\begin{tabular}{|c|c|c|c|c|}
\hline Alias & Mr. A & Miss B & Miss C & Miss D \\
\hline Age & 29 & 28 & 31 & 33 \\
\hline Gender & Male & Female & Female & Female \\
\hline $\begin{array}{l}\text { Educationa } \\
1 \text { level }\end{array}$ & $\begin{array}{c}\text { B.Ed. in } \\
\text { Chinese Education }\end{array}$ & $\begin{array}{l}\text { B.Ed. in } \\
\text { Chinese Education } \\
\& \text { M.A. in Chinese } \\
\text { studies } \\
\end{array}$ & $\begin{array}{l}\text { B.A. in Chinese } \\
\text { language studies \& } \\
\text { B.Ed. in Chinese } \\
\text { language education }\end{array}$ & $\begin{array}{l}\text { B.A. in Chinese } \\
\text { Education and } \\
\text { PGDE }\end{array}$ \\
\hline $\begin{array}{l}\text { Teaching } \\
\text { training } \\
\text { received about } \\
\text { multi-cultural } \\
\text { students }\end{array}$ & $\begin{array}{l}10 \text { weeks } \\
\text { Professional } \\
\text { training course for } \\
\text { in-service teachers }\end{array}$ & $\begin{array}{l}\text { An elective } \\
\text { course in } \\
\text { pre-service } \\
\text { education }\end{array}$ & $\begin{array}{l}\text { An elective } \\
\text { course in } \\
\text { pre-service } \\
\text { education \& } \\
\text { individual } \\
\text { seminars }\end{array}$ & $\begin{array}{l}10 \text { weeks } \\
\text { Professional } \\
\text { training course for } \\
\text { in-service teachers }\end{array}$ \\
\hline $\begin{array}{r}\text { Serving } \\
\text { school type }\end{array}$ & $\begin{array}{l}\text { Direct-subsidiz } \\
\text { ed secondary } \\
\text { school } \\
\end{array}$ & $\begin{array}{l}\text { Aided primary } \\
\text { school }\end{array}$ & $\begin{array}{r}\text { Direct-subsidiz } \\
\text { ed primary school }\end{array}$ & $\begin{array}{c}\text { Aided } \\
\text { secondary school }\end{array}$ \\
\hline $\begin{array}{c}\text { Years of } \\
\text { teaching } \\
\text { multi-cultural } \\
\text { students } \\
\end{array}$ & 7 & 4 & 5 & 10 \\
\hline $\begin{array}{l}\text { Medium of } \\
\text { Instruction }\end{array}$ & Cantonese & Mandarin & Mandarin & Cantonese \\
\hline & \multicolumn{4}{|c|}{ Background information of the student in the relationship } \\
\hline & $\begin{array}{l}\text { S.1 Pakistani } \\
\text { boy }\end{array}$ & $\begin{array}{c}\text { P.4 } \\
\begin{array}{c}\text { Canadian-Chinese } \\
\text { girl }\end{array} \\
\end{array}$ & $\begin{array}{c}\text { P.1 South } \\
\text { African-Chinese } \\
\text { boy }\end{array}$ & S.3 French boy \\
\hline
\end{tabular}

\section{Data Collection}

This study used a qualitative method of interviewing as the main tool to collect data. Purpose of interviewing in this study was to collect data of teachers' stories of teacher-student relationship with multi-cultural students. Interviewing was the most suitable method to capture teacher's expression of both positive and negative affect, and it may provide extra insight into teacher-student relationships that highlight emotional processes. It also offered a window to gain insight into teachers' feelings, beliefs, and expectations in relationships with a particular student (Split \& Koomen, 2009).

The interviews were conducted individually and were a semi-structured interview. The interview guideline consisted of 2 questions, adapted from to Rytivaara \& Frelin (2017): 


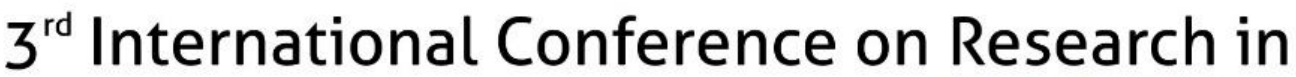 EDUCATION}

1. Please think of a multi-cultural student that caused you trouble but also gave you much joy in Chinese lesson over the past school years. Describe the trouble he/she caused. What have you done to solve the problems?

2. How did this student touch you over the past school years?

Follow-up questions to clarify specific points of view in order to organize why the participants told the stories in that way, evoked more memories about their relationships and connected with more emotional memories, were asked (Craig, 1999). The questions were "Why do you use the word "X" to describe your student?", "Why do you say so?" "Can you describe your relationship with this student/your situation with one word?", "How did you feel when you heard that?" and "What would you do if you could do it again?".

\section{Data Analysis}

After transcribing Cantonese protocols into written Chinese, the protocols were analyzed in 2 stages. In stage 1, the researcher analyzed the protocols into 3 dimensions: the temporal dimension, the social dimension and the position dimension. The temporal dimension was about timeline including the past, the present and the future; the social dimension was people mentioned in protocols and their role; the position dimension was how participants positioned themselves in the protocols (Rytivaara \& Frelin, 2017; van Langenhove \& Harre, 1999).

In stage 2 , the 4 protocols were compared and analyzed by a narrative frame with 4 storylines: problems in the relationship, genuineness and affection, support from other adults and shifts in the relationships (Rytivaara \& Freln, 2017; Harre \& Moghaddam, 2014). After 2 stages of analysis, the original protocols were translated from written Chinese to English.

Table 2: Comparison of the stories and identification of the storylines across the stories

\begin{tabular}{|c|c|c|c|c|}
\hline \multirow{2}{*}{ Alias } & \multicolumn{3}{|c|}{ Four storylines on teacher-student relationship } \\
\cline { 2 - 5 } & Problems & $\begin{array}{c}\text { Genuineness } \\
\text { and affection }\end{array}$ & support & shifts \\
\hline Mr. A & $\checkmark$ & $\checkmark$ & $\checkmark$ & $\checkmark$ \\
\hline Miss B & $\checkmark$ & $\checkmark$ & $\checkmark$ & $\checkmark$ \\
\hline Miss C & $\checkmark$ & $\checkmark$ & & $\checkmark$ \\
\hline Miss D & $\checkmark$ & $\checkmark$ & & \\
\hline
\end{tabular}




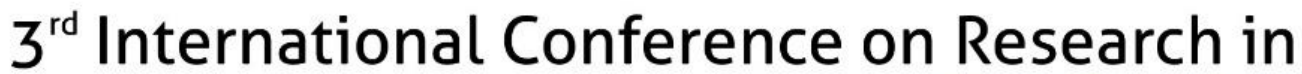 EDUCATION}

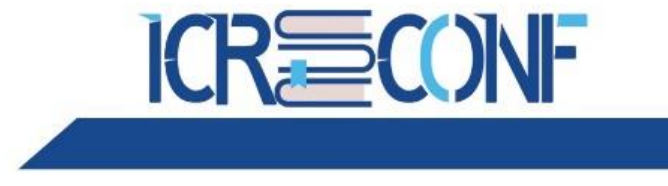

5-7 MARCH 2021 BERLIN, GERMANY

\section{Results}

\section{Problems narrated in the relationships}

Students' behaviour was considered one of the most important correlations of teachers' representations of teacher-student relationships (Split \& Koomen, 2009). Problems in the teacher-student relationships were mainly caused by conflicts with students during Chinese lessons. Besides, "problems" in participants' narrations sometimes included problems from students' caregivers and failure in communicating with serving schools. All the participants narrated problems regarding the student but not all participants faced problems from students' family and their serving schools.

\section{Conflicts in the classroom}

A common problem that occurred in the classroom was behavioural problems, such as crying loudly and shouting (Miss C) and aggressively threaten to the other students (Miss D). Some problems narrated were related to weak Chinese language proficiency. Miss B told a story about the student cheated in Chinese listening assessment. The student did not want to get zero marks anymore, but she could not understand the listening tape in Mandarin, nor read the questions, so she copied the answers from her classmate. There was another story told by Miss $\mathrm{C}$ that related to assessment. Her student always behaved inappropriately especially during unit assessment because the student wanted to achieve better performance, but he was so weak in Chinese. Meanwhile, behavioural problems mentioned by Miss D was about learning motivation and particularly happened in Chinese lesson.

Miss D: "The student resisted learning Chinese very much. He thought that he would go back to France soon, so he did not understand why he had to study Chinese and thought that learning Chinese was meaningless. He was uncooperative during the Chinese lesson. (......) He was afraid while taking Chinese lesson. There were no similar problems when he was taking the other subject lessons, but he was apparently resisting Chinese lesson."

In contrast to the other participants, Although Mr. A's also mentioned behavioural problems of his student, he did not tell a detailed story or a specific incident happened in Chinese lessons. He just took the problem with just one sentence:

Mr. A: "It was difficult to teach this student because of his behaviour in Chinese lesson. He was struggling to follow the class rules. At first, I had nothing to do with him."

He construed the "problem" in the interview question as the struggle faced by students and believed that the source of the problem was the weak Chinese skills the student had. Instead of trouble caused to himself, he described the problem as "The problem he[the student] is facing".

Mr. A: "The student mainly encountered problems with language learning. Some hard-working students might use the copy-writing method, revise repeatedly and 


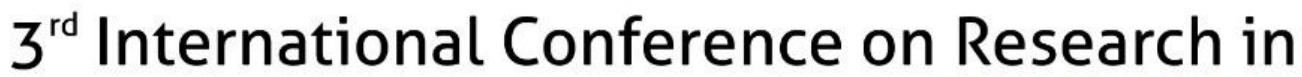 EDUCATION}

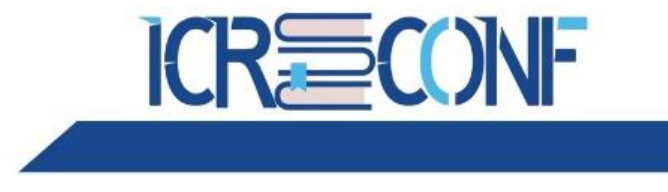

5-7 MARCH 2021 BERLIN, GERMANY

achieved satisfactory results. But when it comes to this student, especially his listening and reading ability, because his language environment is relatively limited, and in our school, students mainly speak English. They don't have to listen to Chinese except Chinese language lessons. There is rarely a suitable language environment to learn Chinese."

When the participants talked about troubles, 3 of them began their stories with students' cultural background. For Mr. A, he first described his student was a Pakistani boy and the time he taught the student was in secondary one. Miss $\mathrm{C}$ described her student's ethnic information and Chinese language knowledge very detailed. Meanwhile, Miss D's narration about students' ethnical background was indirect. The background information of the student was not directly described by the participant but was in the explanation of why the student refused to learn Chinese.

Miss C: "What is unforgettable is that last year when I taught primary one, a student who could not speak Chinese admitted to the school. He came from South Africa last year August, still could not adapt to life in Hong Kong, and the kindergarten he studied in South Africa had no Chinese language curriculum."

Miss D: "There is a student that refuses to learn Chinese because he thought that he would immigrate and go back to France someday."

It implied that cultural differences were also factors that affect the teacher-student relationship. Mr. A also concluded the behaviour problem of the student was due to his cultural background:

Mr. A: "I think children from South Asia countries are more active. To explain negatively, they are naughtier. They always do not obey classroom rules."

Conversely, Miss B did not mention the cultural background of the student. She just described her student as a non-Chinese speaking girl. Even when the researcher made a detailed question about her students' ethnical background, she was not sure about that and only knew that the students' parents could not speak Chinese either. After completing the interview, she asked her colleagues for information and told the researcher about the student's background. Miss B did not consider students' specific cultural background as a place in establishing teacher-student relationship.

Temporal dimension was explicit in Mr. A's \& Miss B's stories. Coincidentally, they both emphasized that the conflicts happened in their first year of teaching that they were inexperienced in catering students' problems.

Mr. A: "That was my first year of teaching, my work was not smooth enough and my communication with students was not good enough."

Miss B: "That was my first year of teaching. I did not realize that I had to follow up with the student." 


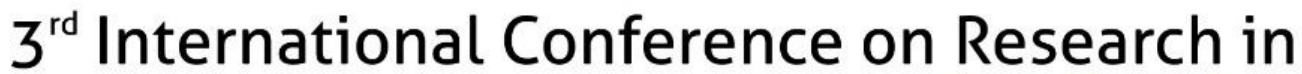 EDUCATION}

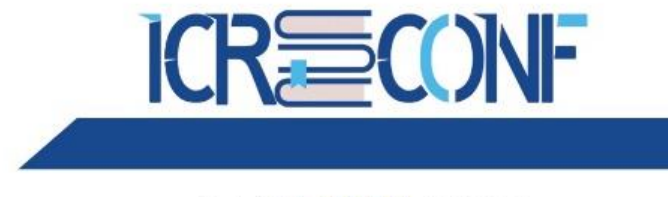

5-7 MARCH 2021 BERLIN, GERMANY

Miss B also reflected on the practice at that time and put forward what changes would occur if she could do better. Her reflection had been extended from a single conflict incident to the reason why students lack confidence in learning Chinese, thus understanding the importance of creating a multi-cultural classroom environment.

Miss B: "If I could do it again, I would create a multi-cultural classroom atmosphere at the beginning of the school year. So that the other classmates would not label this student as a girl who could not speak Chinese."

In this case, not only the student learned Chinese from the teacher but the teacher also experienced from her student (Newberry \& Davis, 2008). From the reaction of other classmates, she noticed that creating a positive emotional atmosphere in a classroom was crucial with regard to students' vulnerable self-image and fear of being teased in front of peers (Arnold, 2011). If the student was confident in speaking Chinese among her peers, it would also improve her Chinese ability. Miss B turned her feeling of guilt of didn't know how to help her student, into a classroom management strategy for teaching Chinese to multi-cultural students. Personal teacher knowledge was created and internalized.

\section{Problems from parents}

Participants often narrated students as victims and attributed student problems to their parents. In the meantime, in their narrations, cultural backgrounds of parents were mentioned. The cultural shock was not only occurred between student and teacher, but also between parents and teacher. In the "cheating story" from Miss B, parents' attitude towards their daughter's cheating was explained by Miss B as also affecting the student's attitude towards learning Chinese.

Miss B: "I guess, I don't know, if parents with these [multi-cultural] background think [their children being] happy is more important. They did not excessively boost their children to learn Chinese. She [the student] failed in all Chinese papers, so [her parents] did not mind if she failed in the listening paper either. (......) [Student's] dad is an intellectual and reasonable person. That school year was important to the student because she was going to be promoted to secondary school [the student need to prepare for the Secondary School Places Allocation Exam]. However, her father still didn't boost her academic result in Chinese, and even said that the most important thing was his daughter was happy."

Miss D found that the student's negative attitude towards Chinese language was very similar to his parents' attitude. Dialogue "will immigrant" from the student was repeated by the parents. Mother of the student even suggested the participant exclude the student in Chinese lesson.

Miss D: "The response of the parents was that he [the student] has always disliked Chinese, so you don't need to force him to learn. Our school certainly did not allow this attitude. Even when the vice-principal contacted the parents, the attitude of the parents was that we will immigrate soon, this school was near their home so they 


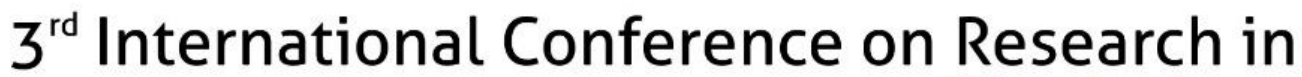 EDUCATION}

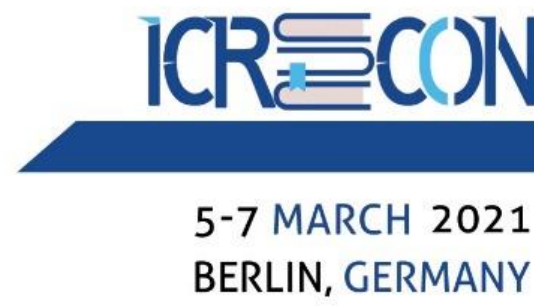

chose to study in this school. If he really can't learn Chinese, you can leave him behind."

\section{Powerlessness}

When it comes to solving problems with the student, Miss B obviously showed a feeling of powerlessness and feeling of guilt, and the sense was derived from school policies. Even when she was the Non-Chinese speaking Students Development Officer of school, Miss B had very little power in developing curriculum for multi-cultural students. Many school policies such as class size, the use of Putonghua as the medium of instruction for teaching the Chinese Language Subject and lack of support to multi-cultural students made her feel that she could not help her student.

Miss B: "This [education] system cannot help multi-cultural students in mainstream education in large classes or even in "Putonghua as the medium of instruction". Even the school itself questioned their abilities in learning Chinese. (... ...) My school's policy is relatively unsatisfactory, that is, the government has subsidized, and the school also receives subsidies, but it is lack of flexibility."

She positioned herself as a "teacher who can't help" and mentioned more than once that she could help. The listed narrations showed that she felt useless in helping her student improved.

"When it comes to academic results, my work was useless."; "There was a big difference in learning progress [among the students]. Designing worksheet could not help a lot to them [multi-cultural students]."

"Academically, I could not help her a lot."

"At that time, I felt that it was difficult for me to improve to her immediately. Learning Chinese and English is since one was little. The difference between her and her classmates could be very big. Even if she was interested to learn, I may not be able to help her in class."

"I taught her nothing."

In addition to the feeling of powerlessness from thinking that one's teaching is ineffective, Miss B and Miss D showed helpless when they sought help from the other teachers but in vain. Miss B explained the subject meeting of her school which difficulties and teaching strategies would not be discussed. The school would require teachers to share the content of professional training they attended in the meeting, but she believed that these contents could not meet the needs of the school. Therefore, Miss B narrated her colleagues "completely not helpful" in the situation. Miss D's colleagues gave her suggestions to teach the student but she thought the solutions were useless.

Miss D: "The opinions given by my colleagues were all about punishments, isolation, and even suggested me to ask the student to go to the sick room while class observation. These methods were suggested to avoid problems instead of dealing with the situation. (......) I don't think the disciplinary and counselling unit could deal with him, and the head of disciplinary only suggested me to exclude him." 


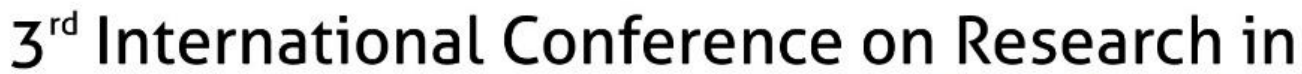 EDUCATION}

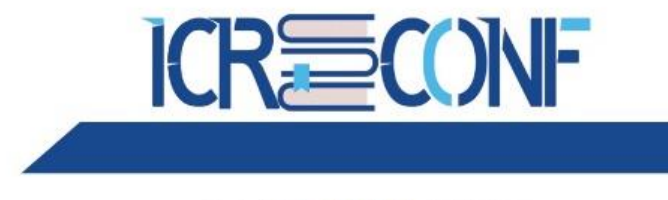

5-7 MARCH 2021 BERLIN, GERMANY

In sum, there were problems in the teacher-student relationship. The problems were about students' misbehaviour during Chinese lessons and Chinese language assessments. The reason behind the conflicts was also related to the students' academic achievements, which became the tension in establishing the teacher-student relationship.

\section{Genuineness and affection}

In the complexity of the teacher-student relationship, in addition to the above-mentioned conflicts, positive relationships were also an essential part of the same relationship.

Miss D believed that multi-cultural students were easily expressed their emotions. "Genuineness", "happiness" were her wordings to describe the French student even when the boy caused him a lot of trouble in Chinese lesson. At the end of the interview, she concluded that she loved to teach multi-cultural students. Miss B, the teacher of the South African-Chinese boy who was nervous and loses his temper during every Chinese assessment, also stated that she loved teaching multi-cultural students after the interview. Other participants also narrated that students expressed fondness emotions to them.

\section{Witness the growth of students}

Genuineness from students narrated by participants marked the growth of the students. Mr. A described that one time he received the birthday card written in Chinese and used the word "touched" twice. Miss $\mathrm{C}$ described the most unforgettable moment with her student was the shift in doing the assessment.

Miss C: "The happiest thing was that the boy learned how to try in the process. For example, during the assessment (......) One time, he finally did not cry, and he happily took my hand to tell me, "Miss C, look at me, I am smiling", and then he laughed. It could be seen that he had actually learned something. Although he has not made great progress in learning Chinese, he had learned how to face these difficulties."

The above-mentioned warmth movement was one-time situations. Besides, some fondness move happened after the school year was over. "Timeline" in Mr. A's story was since his first year of teaching, extended to more than 6 years. The touching moment was happening when the student "succeed in learning" and "admitted to the Education University OF Hong Kong through JUPAS". Miss B's student's fondness was happening continuously for over 2 years. A small movement of greeting made Miss B "felt that I could build a relationship with her."

Miss B: "I taught this student 2 years ago. Last year and recently, when she saw me in the corridor, she would greet me initiatively."

\section{Indirect narration}

Less positive interaction was narrated by Miss B than the other participants. However, there was some subtle affectional behaviour shown from Miss B's student, for example, greeting when they meet in the corridor. Their relationship, on the good side, was also 


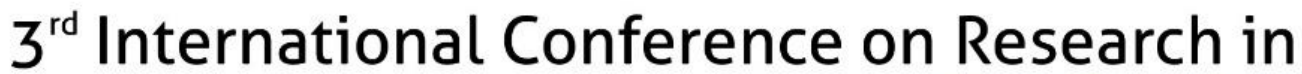 EDUCATION}

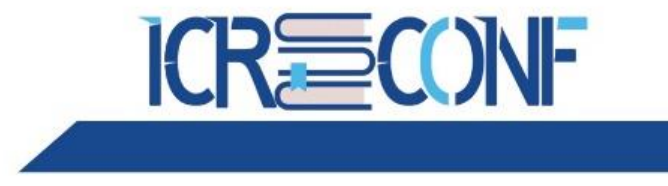

5-7 MARCH 2021 BERLIN, GERMANY

conveyed from student's parents. After describing how the student's parents react to cheating in examination, she told the researcher about how "trouble" the parents described by her colleagues. When the researcher asked if the parents would complain about her either, she replied that surprisingly, the parents said that she taught the girl well and the girl loved her so much. Even when Miss B disagreed that she could help the student, a little positive relationship was expressed indirectly.

\section{Parent-child relationship analogy}

Affection from the student described by Miss D was taking some features of a family relationship (Rytivaara \& Freln, 2017). A positive situation happened in an award presentation ceremony that the student treated her as a family member.

Miss D: "He got the first place in other subjects. In our school, we would invite parents to receive awards with the student together on the stage. This student told me that his parents had received awards with him already, so he invited me to go onto the stage with him to take photos. After that, he got a flower that was supposed to give to his parents, but he gave it to me, said I was like his mother, his sister."

\section{Support from the other adults}

Parents and colleagues were the major sources of support of the other adults in participants' narrations. In contrast to the caregivers and teachers that caused powerlessness narrated in Miss B and Miss D's stories, Mr. A and Miss C Considered the effort of collaboration with parents as well as colleagues as an important part of helping students solve problems.

\section{Recognition of parents' effort}

Mr. A positioned student's father as a big help to himself. He found that parents of his student had the "sense of crisis". The parents agreed that learning Cantonese was important to living in Hong Kong. Mr. A concluded that multi-cultural parents were more attentive to the discipline of their children learning Chinese, so he knew where to seek help when he wanted to cater to students' behavioural problems. He concluded that cultural differences were one of the solutions to help the student improve.

Mr. A: "Facing with this ethnicity, [seek help from] the home discipline is very effective."

Miss C mentioned the word "supportive" twice in her narration when it comes to parent-teacher collaboration. She gave the researcher detailed information about what the father had done for his child.

Miss C: "After their family came to Hong Kong, they had communicated with me before the start of the school year. They told me that the child could not speak Chinese at all and he might need more guidance. (......) For the sake of the child's study, [the student's father] chose not to work in the first year in Hong Kong, so that he could "full-time" accompany the child. (.....) The father would come to pick up 


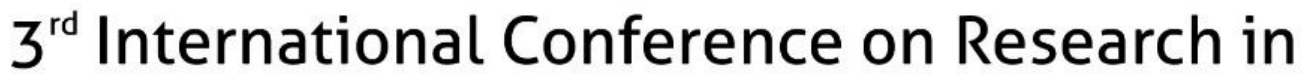 EDUCATION}

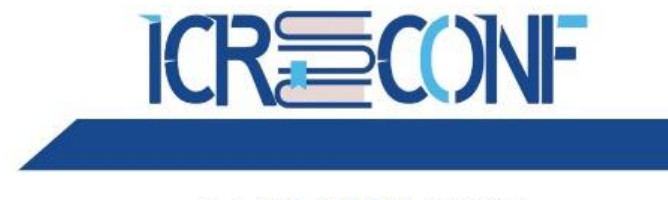

5-7 MARCH 2021 BERLIN, GERMANY

the child after school every day so that he could understand what difficulties he had in class and learned how to help the child."

Both participants named the family member and their role in providing support to themselves, but the role of the fathers was different. Father of Mr. A's student was here to help improve student with his behavioural problems. Father of Miss C's student was a Chinese speaker, and the help from this father was assisting the student to do Chinese homework.

Mr. A: "His father is more dignified, so he listens more to his father."

Miss C: "His father is a Hong-Konger, and his father mainly teaches children to do Chinese homework."

\section{Interaction narrated with other adults}

In Miss C's narration, she was not only telling how the father supported her and the student, but also how she taught the father how to help the child learn Chinese. This "parent education" part was more detailed. Parents' support here was not one-way but full of interaction and fully reflected the importance of home-school cooperation.

Miss C: "For example, I would tell him how to do revision with the child after returning home, such as telling him to select keywords in each unit to revise, and don't force the child to learn all the words, let him have at least one goal and feel more successful. There are also ways to write and literate, such as teaching him how to write vocabulary cards at home, how to practice reading aloud, because we teach Chinese in Putonghua, we need to teach the father some pinyin methods, first, read the initials, then the finals, To distinguish the tones, and then read them out. In addition, I taught the father some literate skills, which can be applied at home. I had also made some brochures, which were strategies that the father could use at home, so that the father could, so as to improve children's literacy as soon as possible in the first grade."

Discussing the curriculum development for multi-cultural students together was the greatest support provided by other colleagues to Mr. A and Miss C. This might be attributed to the benefits of direct-subsidized schools, because the curriculum development of this type of schools was relatively flexible, and the school could design "tailor-made" education according to the needs of students and the school-based situation. Mr. A named Chinese Language subject panel and used an activity suggested by her as an example to explain the role of support from his colleague. The subject panel designed a lesson to learn Chinese by making fruit punch with the students.

Mr. A: "Collaboration between our colleagues could also help construct the curriculum. Frankly speaking, I couldn't think of activities like making fruit punch, and I didn't particularly want to do it. But I understand that this activity had fun for the students. The subject panel designed it in this way, which made them happily learn to make a cup of mixed fruit punch. A lot of Chinese language teaching was infiltrated in it. The entire lesson design and teaching process were created by our colleagues, and we could learn from each other." 


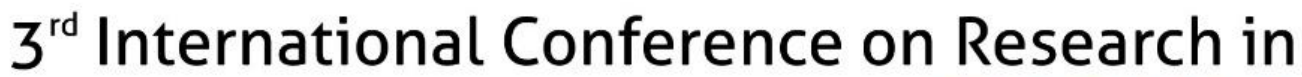 EDUCATION}

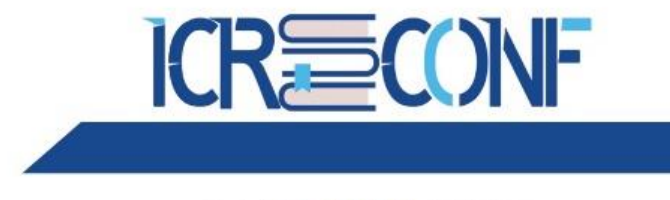

5-7 MARCH 2021 BERLIN, GERMANY

In Miss C's narration, more people were involved in helping the student including Chinese Language subject panel, curriculum development officer and the principal. But in her narration, details of school policies for multi-cultural students were given rather than how the policies helped her build the relationship or teach Chinese more effectively.

To conclude, every single little act from the student could be the evidence of the positive relationships that both the participants and the students created. It could be found that the more help from the other adults in the narrations, the more detailed positive acts could be told in the stories. Meanwhile, strong positive teacher-student relationships could last long even when the participants are not teaching that student anymore.

\section{Shifts in the relationship}

This storyline was about how from the teacher-student relationship changed because of the change in students' behaviour from the participants' perspective (Rytivaara \& Frelin, 2017). In most of the stories, participants were the one who took initiative in helping students and making changes. Their narrations were about what they had done to help students solve the problems and the stories ended with students' changes that improve the relationships.

Language proficiency was about communicating in daily lives (林偉業，2013). Mr. A's stories paid attention to the cultural response and helping students adapt to living in Hong Kong. Taking students to take light rail around the school, eating famous chained rice noodle restaurants, were his ways of building a relationship with multi-cultural students at risk. Also, he created a classroom atmosphere that respected students' hometown cultural and daily lives, for example, while teaching Chinese cultural and Chinese idioms, Mr. A always required his student to share Pakistani food culture and Pakistani idioms with him. Mr. A thought that experience sharing was a way to improve the teacher-student relationship.

Mr. A: "All students would share their own life experiences and we [our relationship] would get closer. Of course, the experiences must all be spoken in Chinese, which was also training their speaking ability. But these would make everyone more engaged [in the Chinese lesson]."

In sum, Mr. A grasped any chance to create valuable teaching moments, both for learning and building relationships, to daily life. Conversations that change lives ranged beyond the narrow concerns of academic only (Gaff, 1973).

Even though Miss D described her student as "bad" for more than once, and there were isolation and helpless situation from her narration, she still treated her student with an attitude of never giving up because of the student.

Miss D: "The student is still living in Hong Kong at this moment, and he should learn more Chinese at this moment, so he would not be deceived when he goes out or knows how to order food. (......) I want to do more and see if I can make the whole situation a little better." 


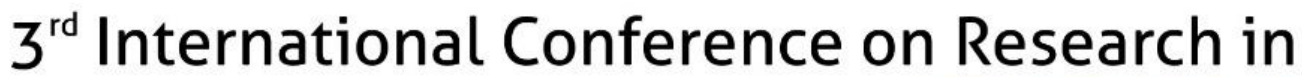 EDUCATION}

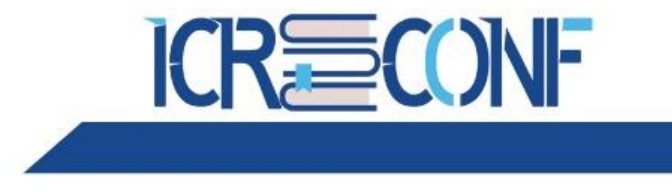

5-7 MARCH 2021 BERLIN, GERMANY

In contrast to Mr. A's situation, due to inflexible policies from her serving school, her approaches to help student were mostly inside the classroom. She discovered that the student was victorious, so she designed games to help his revision. Also, she broke down the learning goals with the student, and only revised the key points in one assessment paper with him, so that student could achieve a sense of success, and hoped that this sense of success could be extended from one paper to other assessment papers. When her student improved, no matter how big the improvement was, she would affirm that he put in a lot of effort into learning. She also narrated a single event that the student showed his interest in learning Chinese and thank the teacher for using effective methods. The inadvertent goodwill from students helped to establish a good teacher-student relationship.

Miss D: "In my school, we would teach a Chinese character in the assembly every day. One day, the student told me that because the teacher [ in the assembly] teach the character in Chinese, he could not understand what the teacher said. I asked him if anything he could not understand, he replied to me that he could recognize that character, but he could not understand the explanation from the teacher. I tried to explain the structure of the character in assist of English and drawing. The character was easy, it was understandable to the students, but they could not comprehend the explanation. To multi-cultural students, it was not easy to understand the explanation in that way. After I taught the character in my way, the student said in English, "This is teaching!" I was happy with that."

When Miss B narrated her relationship with the student, her speech was uncertain. She tried to find an explanation for their positive relationship, but she would not say with certainty that it is the result of her hard work or strategies used. She emphasized that she had done nothing with helping the student learn Chinese as well as building a relationship.

Miss B: "I think it's because I never scold her. (......) Maybe I tried to comfort her, so she thought I was good."

Instead of putting effort into teaching Chinese, Miss B thought that the student was not afraid to go to school, be able to study happily was more important. She built teacher-relationship with the student by assigning her to be the class monitor, giving her small tasks such as distributing workbooks to her classmates.

Miss B: "I hope she understands that the teacher does not just value your grades. Maybe your Chinese is poor, but it doesn't mean that the teacher will dislike you, or scold you, or force you to revise."

The students' needs for connection met by this warm, friendly and not subject-oriented teacher (McKeachie, 1961). In conclusion, Miss D treated the student with an understanding and respect even when the student was disrespectful. Understanding students and being considerate to them as a person are closely related to the students' motivation to learn (Park, 1991). 


\section{$3^{\text {rd }}$ International Conference on Research in EDUCATION}

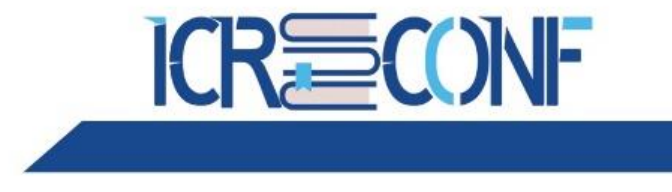

5-7 MARCH 2021 BERLIN, GERMANY

\section{Discussions}

The goal of this research is to investigate different aspects of teacher-relationship by exploring teachers' stories from 4 kinds of school. How to build success teacher-student relationship was expected to be discussed and added to the landscape of teacher knowledge.

\section{Individual teacher knowledge acquisition}

In Chinese tradition, the education system is shaped by teacher-centeredness ( $\mathrm{Li} \& \mathrm{Du}$, 2013). From Xunzi "a person of noble character should respect his teachers" to "the teacher is lazy if the education is not rigorous", the teacher-student relationship was a non-equal relationship. The teacher is the representation of knowledge and wisdom ( $\mathrm{Li} \& \mathrm{Du}, 2013$ ), the status of the teacher is an unshakable authority for the students (叶子、庞丽娟, 1999). Teachers and students are interpreted as educators and be-educated, controllers and obediencers (王俊菊、朱耀云，2010). It was the student's responsibilities if his/her academic result was not good and could not adapt to the schooling system.

Nowadays, when education is modernized, whether the teacher-student relationship still has absolute master-subordinate nature is worth considering. Participants in this research obviously no longer affected by the tradition, but instead value the differences of each student. In the stories, Miss B attitude towards her student who eventually refuses to speak Chinese to be specific, feelings and emotion of students were of most importance to the teacher.

Affirmative teacher-student relationships in the stories have the characteristics of family relationships and peer relationships. The teachers treated the students as a friend, rather than a subordinate subject, understand their need to adapt to life in Hong Kong and difficulties in learning Chinese, and provided more individual support both academically and in daily life. The image of the teachers was determined by "strict fathers" changed to "loving mothers". Mr. A's story strongly shows the characteristics of peer relationships. He cook and ate out with students, and share their lives just like friends. It aligned with the research result of 張慧明 (2018) stated that Hong Kong teachers were confidence in establishing positive and trusting relationships with non-Chinese speaking students.

Teachers' knowledge and beliefs are influenced by the prompt situations in the classroom and of the students (Hoy, Davis \& Paper, 2006). Teachers who were sensitive to the struggles and desiderata of their multi-cultural students may use interaction styles and pedagogical practices that took advantage of these students' strengths and life experiences (Bingham \& Okagaki, 2012). The participants showed how teachers understand students with ethnical feature, motivation and language learning difficulties related to the quality of teacher-student relationship. Relational knowing, nested knowing and embodied knowledge as a part of teachers' personal practical knowledge were demonstrated A teacher's knowledge was no longer came up with as bounded and separate from the knowing of the others. When building relationship, a teacher caring for his or her student, and when the student responded to the caring, the knowing of these two persons interacted in an intersubjective way (Hoy, Davis \& Paper, 2006).

.Recognition of individual differences is one of the connotations of teacher knowledge (Shulman, 1986). How well the teacher knows about the student, skills to communicate with the student at risk or with multi-cultural background and cultural awareness (Shulman, 1986) 


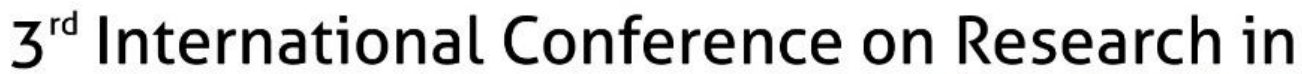 EDUCATION}

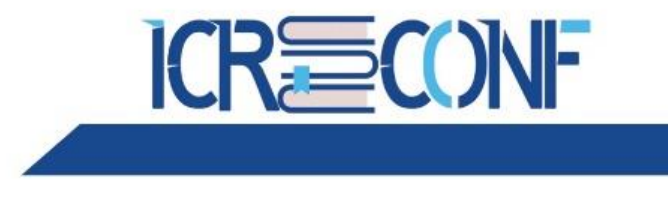

5-7 MARCH 2021 BERLIN, GERMANY

are considered to be teaching specific techniques in the stories. For instance, Miss D understood her student's personal characteristics by observation, and then designed activities that could improve his participation in the lesson, and finally achieved further progress in academic achievement. Another example was Mr. A knowing that the cultural characteristics of the Pakistani student and his family, even if this characteristic is different from ordinary people's perception, he could use these cultural background knowledge to help the student solve behavioural problems. This kind of teacher knowledge is strongly related to his own experiences and situation. Such reflections of the participants from their stories can contribute to their individual element in teacher knowledge (Verloop, Van Driel \& Meijer, 2001).

\section{Relationship network connection}

The teacher-student relationship is far more than teachers and students only and is embedded in a network of other relationship (Rytivaara, Frelin, 2017). In the stories, it can be seen that there were different stakeholders having a certain impact on relationship building regardless of good or bad. Parents and colleagues were frequently mentioned. "Two hands are better than one", creating close collaboration relationship network can help students in need more effectively and achieve more in relationship building because both teacher and student know where to seek help when they have conflicts or encounter problems. In addition, peers also influence teacher-student relationships in some circumstances.

The teacher stories have implication for parent education. Maintaining good communication with parents is very important. Inevitably, teachers may meet parents who are uncooperative like the parents in Miss D's story. In addition to building a good teacher-student relationship, it is also very important to build a relationship with parents. Teachers have to master good communication skills and parent education skills, and they must understand the difficulties of parents as well as the cultural background of the students. Miss B's story inspires us that "teaching parents to teach" is also important. Sometimes, parents may not want to help their children, they just don't know how to help. There are 4 kinds of strategies suggested to teach parents. Firstly, strategies to help children manage behaviour in daily routines could be taught (Mahoney, Kaiser, Girolametto, MacDonald, Robinson \& Safford, 1999). Secondly, basic linguistic knowledge such as Mandarin pinyin, the structure of Chinese characters and daily teaching content could be told to parents so that they can follow up what the children have learnt. Thirdly, learning strategies such as character de-coding, use of graphs (羅燕琴, 2016) are suggested so that parents can master the ways to help their children in Chinese language. Lastly, teachers may communicate with parents with their parental expectation. In Miss B and Miss D's stories, parents with low expectation towards their children caused them to pay no attention to the academic results or even their own behaviour. Studies found that parental expectations appeared to be related to ethnic minority students' academic self-efficacy and higher parental expectations encourage home-school cooperation (Yamamoto \& Holloway, 2010).

Achieving the above goals of communicating with parents is never easy. In Mr. A's story and Miss B story, memories of being at a loss for students' problems because of lack of experience were recalled. Basic counselling skills, relationship building strategies and knowledge about multi-cultural students in Hong Kong are suggested to be included in teacher education (Rytivaara \& Frelin, 2017). More training to student-teacher about teaching Chinese as a second language, for instance, learning strategies, curriculum development skills is also considered. 


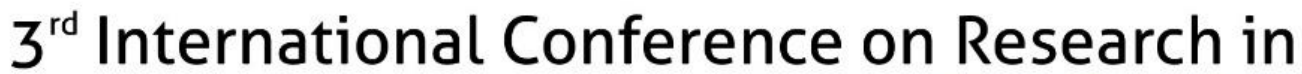 EDUCATION}

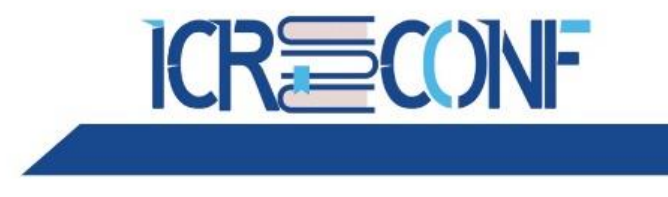

5-7 MARCH 2021 BERLIN, GERMANY

The teachers mentioned how their colleagues gave support or discouragement in building a teacher-student relationship. A healthy school support network is significant to help teachers encounter problems with students. How the disciplinary unit, Chinese subject team and Curriculum development officer attitudes towards multi-cultural students influences their support to multi-cultural students as well as their teachers in need. The successful experiences of "whole-school approach", which provides mental and emotional support to students at risk (Weare, 2000) may be a way to go by. The role of other stakeholders, for instance, educational psychologists, multi-cultural teaching assistants, which were not mentioned in the narrations, are suggested to be included in the school support network. Special curriculum design may also help multi-cultural students adopt to Chinese language learning. Mr. A's narrations demonstrated a flexible curriculum with a down-to-earth and practical language learning design that can help improve the teacher-student relationship because teachers were teaching something relevant to their everyday lives.

Role of classmates, who were often mentioned in the narrations but had not been explained thoroughly, was also worth taking note of. One of the reflections in Miss B's story was about to create a multi-cultural environment in her classroom to avoid racial discrimination. Turn a blind eye to bullying or teasing leads to a breakdown in relationships. It is the teacher's responsibility to create an appropriate atmosphere that everyone, including local students and multi-cultural students, is respectful and accepting each other in order to enhance social interaction (Carrasquillo \& Rodríguez, 2002). Inclusion classroom management helps the student learn not only content on textbooks, but a new set of communicative conversions in the meantime (Jordan \& Joesting, 1983). Furthermore, teachers need to aware of the unintended act from local, or other students, that cause multi-cultural students feeling uneasy (Willis, Thompson, \& University of Missouri - Kansas City,2003). To conclude, the classroom community shall be considered as part of the relationship connection network.

\section{Impact beyond time and space}

Different from the existing research results, stories from Mr. A and Miss B with explicit temporal dimension in this research reflect that the teacher-student relationship had not been affected by the passage of time, and even some of the warmth and intimacy of the relationship was shown after the end of the teaching year. It is inferred that a positive teacher-student relationship promotes a long-term impact on students, in academic aspect and personal development aspect. Ethnical minority students altered their behaviour, and their determination to pursue better academic performance, in long term, was found in studies in the US (Willis, Thompson \& University of Missouri - Kansas City, 2003). It is hoped that similar effects can be demonstrated among students with multi-cultural backgrounds in Hong Kong so that teachers' efforts and a good teacher-student relationship can nourish children's lifelong happiness.

The changing in students are beyond classrooms. In the stories, it is found that curricula that lead to effective teacher-student relationship building are about daily lives. Some of these children will continue to study in Hong Kong, and some may return to their hometowns in the future. Whatever happens, the good teacher-student relationship prepared them the basic conditions for learning Chinese well, so that they could integrate into Hong Kong life by 


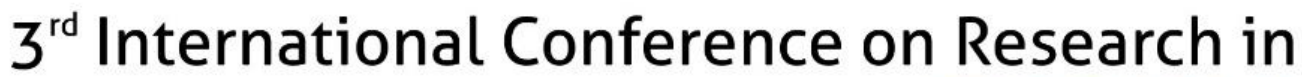 EDUCATION}

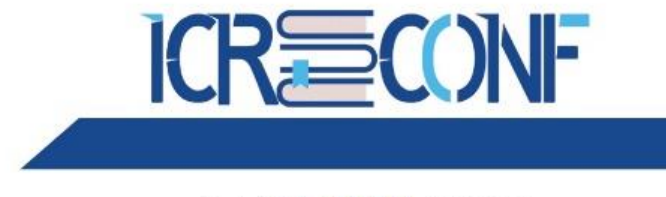

5-7 MARCH 2021 BERLIN, GERMANY

learning practical communication skills. The communities where they live will also benefit from youngsters that could adapt to a new culture.

\section{Conclusion}

A good teacher-student relationship makes the teacher's work full of satisfaction and success. It is shown that participants' relationships with their multi-cultural students was one of the primary sources of their everyday emotional experiences and wellbeing because teacher-student relationships contributed to a basic need for relatedness (Spilt, Jantine, Koomen, Helma, Thijs \& Jochem, 2011). Miss B, whose relationship with her students was not as close as the other three teachers and their students, the feeling of isolation and tiredness was obvious in the narrative. She also pointed out in the later supplement that she was about to resign from her serving school. In contrast, the other teachers used positive words such as "interesting", "geeling easy", "satisfying", "happy", "I like it" reflected that they were satisfied with what they had done in building teacher-student relationship. These satisfactions will have a certain effect on their continued involvement in the challenging education industry in the future.

Chinese teachers of multi-cultural students work very hard, but they find it difficult to teach due to lack of training, caused full of frustration and helplessness. Due to the lack of Chinese cultural background and ethnic characteristics, multi-cultural students are more active. Teachers need to select appropriate teaching strategies for their special circumstances, but the previous teacher training in Hong Kong did not provide this kind of training (張慧明, 2015). If teachers lack the understanding of students' background, culture, and learning diversity, and fail to cater for the needs of students of different cultures in teaching, students' chances of academic achievement will be reduced accordingly (Au \& Blake, 2003). At present, the courses for learning Chinese as a second language are not compulsory in teacher training. As more multi-cultural students have the need to learn Chinese in Hong Kong, training for new teachers and in-service teachers needs to be considered.

\section{References}

Arnold, J. (1999). Affect in Language Learning. Cambridge: Cambridge University Press.

Arnold, J. (2011). Attention to Affect in Language Learning. International Journal of English Studies, 22 (1), 11-22.

Au, K. H. \& Blake, K. M. (2003). Cultural Identity and Learning to Teach in a Diverse Community. Journal of Teacher Education, 54(3), 192-205.

Baker, J. A., Grant, S., \& Morlock, L. (2008). The teacher-student relationship as a developmental context for children with internalizing or externalizing behavior problems. School Psychology Quarterly, 23(1), 3-15. 


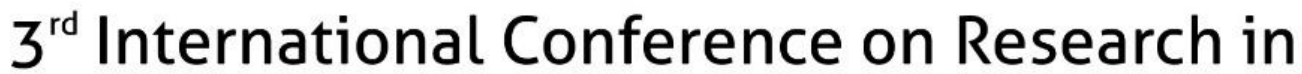 EDUCATION}

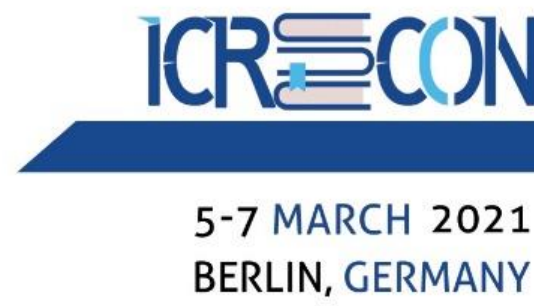

Bingham, G. E. \& Okagaki, L. (2012). Ethnicity and Student Engagement In Handbook of Research on Student Engagement (2012 ed., pp. 65-96). Boston, MA: Springer US.

Bloom, B., Hastings, J., \& Madaus, G. (1971). Handbook on formative and summative evaluation of student learning. New York: McGraw-Hill.

Bush, R. (1954). The teacher-pupil relationship (Prentice-Hall education series). New York: Prentice-Hall.

Carrasquillo, Angela, L. \& Rodriguez, V. (2002). Language Minority Students in the Mainstream Classroom. Clevedon: Channel View Publications.

Chambers, R. (1984). Story and situation: Narrative seduction and the power of ficction. Manchester: Manchester University Press.

Claessens, L., van Tartwijk, J., Pennings, H., van der Want, A., Verloop, N., den Brok, P., et al. (2016). Beginning and experienced secondary school teachers' self- and student schema in positive and problematic teacher-student relationships. Teaching and Teacher Education, 55, 88-99.

Clandinin, D. J. (1992). Narrative and story in teacher education. In T. Russell, H. Munby Teachers And Teaching: From Classroom To Reflection (pp. 121-134). London: The Falmer Press.

Clandinin, D. J. \& Connelly, F. M. (1996). Teachers' Professional Knowledge Landscapes: Teacher Stories-Stories of Teachers-School Stories-Stories of Schools1. Educational Researcher, 25(3), 24-30.

Connelly, F. L. \& D. Jean Clandinin, D. J. (1990). Stories of Experience and Narrative Inquiry. Educational Researcher, 19(5), 2-14.

Connelly, F. M. \& Cladinin, D. J. (1995). Narrative and Education. Teachers and Teaching, $1(1), 73-85$.

Craig, C. J. (1999). Parallel stories: A way of contextualizing teacher knowledge. Teaching and Teacher Education, 15(4), 397-411.

Davidson, A. L. (1999). Negotiating social differences: Youths' assessments of educators' strategies. Urban Education, 34(3), 338-369

Davis, H. A. (2003). Conceptualizing the role and influence of student-teacher relationships on children's social and cognitive development. Educational Psychologist, 38(4), 207-234.

Den Brok, P., Levy, J., Brekelmans, M., \& Wubbels, T. (2005). The effect of teacher interpersonal behaviour on students' subject-specific motivation. Journal of Classroom Interaction, 40(2), 20-33.

Dewaele, J., Witney, John, Saito, Kazuya \& Dewaele, L.. (2017). Foreign language enjoyment and anxiety: The effect of teacher and learner variables. Language Teaching Research : LTR, 22(6), 676-697.

Doecke, Brenton, Brown, Jenny, \& Loughran, J. (2000). Teacher talk: The role of story and anecdote in constructing professional knowledge for beginning teachers. Teaching and Teacher Education, 16(3), 335-348.

Engels, et.al. (2016). Behavioral Engagement, Peer Status, and Teacher-Student Relationships in Adolescence: A Longitudinal Study on Reciprocal Influences. Journal of Youth and 


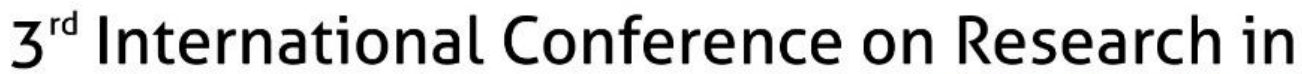 EDUCATION}

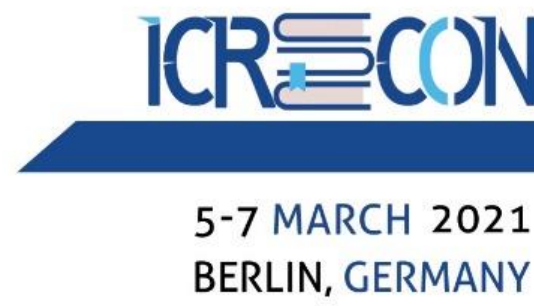

Adolescence, 45(6), 1192-1207.

Etikan, I., Musa, S. A. \& Alkassim, R. S. (2016). Comparison of Convenience Sampling and Purposive Sampling. American Journal of Theoretical and Applied Statistics, 5 (1), 1-4.

Frymier, Ann, B. \& Houser, M. L. (2000). The teacher-student relationship as an interpersonal relationship. Communication Education, 49(3), 207-219.

Gaff, J. G. (1973). Making a Difference: The Impacts of Faculty. The Journal of Higher Education, 44(8), 605-622.

Gardner, R., \& Lambert, W. (1972). Attitudes and motivation in second-language learning. Rowley, Mass.: Newbury House.

Hamre, B. K., \& Pianta, R. C. (2001). Early teacher-child relationships and the trajectory of children's school outcomes through eighth grade. Child Development, 72(2), 625-638.

Hoy, A. W., Davis, H., \& Pape, S. J. (2006). Teacher Knowledge and Beliefs. In P. A. Alexander \& P. H. Winne (Eds.), Handbook of educational psychology (p. 715-737). Lawrence Erlbaum Associates Publishers.

Jantine, L. S., Jan, N. H., Wu, J. Y. , \& Kwok, O. M. (2012). Dynamics of Teacher-Student Relationships: Stability and Change Across Elementary School and the Influence on Children's Academic Success. Child Development, 83(4), 1180-1195.

Jordan, C., and Joesting, A.K. (1983). Patterns of classroom interaction with PacificIsland children: The importance of cultural differences. In M. Chu-Chang (ed)Asian-and Pacific-American Perspectives in Bilingual Education (pp. 216-42).New York: Teachers College Press.

Ladd, Gary W, \& Burgess, K. B. (2001). Do Relational Risks and Protective Factors Moderate the Linkages between Childhood Aggression and Early Psychological and School Adjustment? Child Development, 72(5), 1579-1601.

Lavy, S.\& Bocker, S. (2017). A Path to Teacher Happiness? A Sense of Meaning Affects Teacher-Student Relationships, Which Affect Job Satisfaction. Journal of Happiness Studies, 19(5), 1485-1503.

Lee, G.\& Schallert, L. (2008). The teacher-student relationship as a developmental context for children with internalizing or externalizing behavior problems. Journal of Second Language Writing, 17 (3), 165-182.

Li, H. C. \& Du, X. Y. (2013). Confronting Cultural Challenges When Reconstructing the Teacher-Student Relationship in a Chinese Context, In M. J. Kirkebæk Teaching and Learning Culture: Negotiating the Context (pp. 79-94). Rotterdam: Sense Publishers.

Lingard, B., Hayes, D., \& Mills, M. (2003). Teachers and productive pedagogies: Contextualising, conceptualising, utilising. Pedagogy, Culture \& Society, 11(3), 399-424.

Lochman, J. E. (2003). Commentary: School Contextual Influences on the Dissemination of Interventions. School Psychology Review, 32(2), 174-177.

Lubchenko, S. (2016). Service learning creates a positive relationship between teachers and students. Journal of Character Education, 12(1), 81.

Mahoney, et.al. (1999). Parent Education in Early Intervention. Topics in Early Childhood Special Education, 19(3), 131-140. 


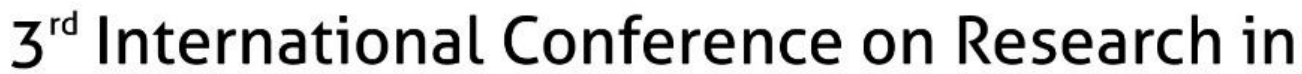 EDUCATION}

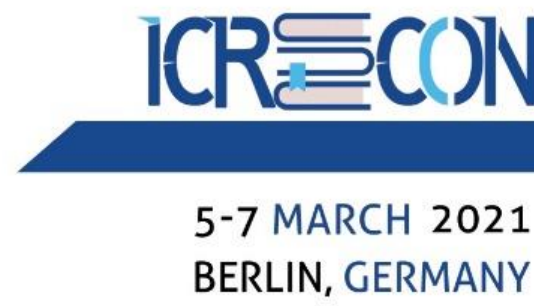

Masgoret, A. M. \& Gardner, R. C. (2003). Attitudes, Motivation, and Second Language Learning: A Meta- Analysis of Studies Conducted by Gardner and Associates . Language Learning, 53 (1), 123-163.

Mckeachie, W. J. (1961). Motivation, teaching methods, and college learning. In M. R. Jones 3ewasymposium on motivation (pp. 111-142). Lincoin: University of Nebraska Press.

Meehan, B. T., Hughes, J. N. \& Cavell, T. A. (2003). Teacher-Student Relationships as Compensatory Resources for Aggressive Children. Child Development, 74 (4), 1145-1157.

Morris, P., \& Adamson, B. (2010). Curriculum, schooling and society in Hong Kong. Hong Kong: Hong Kong University Press.

Newsberry, M. \& Davis, H. A. (2008). The role of elementary teachers' conceptions of closeness to students on their differential behaviour in the classroom. Teaching and Teacher Education, 24, 1965-1985.

O'Connor, E. (2010). Teacher-child relationships as dynamic systems. Journal of School Psychology, 48, 187- 218.

Olson, M. R. (1995). Conceptualizing narrative authority: Implications for teacher education. Teaching and Teacher Education, 11(2), 119-135.

Park, Y. (1991). The effect of teacher-initiated student-teacher personal relationship beyond the classroom upon academic achievement and attitude of selected students at Korea Baptist Theological College/Seminary.

Population by-census Main Results (2016). Retrieved from Census and Statistics Department, Web site: https://www.statistics.gov.hk/pub/B11200982016XXXXB0100.pdf

Riley, P. (2009). An adult attachment perspective on the student-teacher relationship \& classroom management difficulties. Teaching and Teacher Education, 25(5), 626-635.

Rytivaara, A., Frelin, A. \& (2017). Committed to trouble. Learning from teachers' stories of challenging yet rewarding teacher-student relationships. Teaching and Teacher Education, 68, 12-20.

Shulman, L. S. (1986). Those Who Understand: Knowledge Growth in Teaching. Educational Researcher, 15(2), 4-14.

Spilt, J. L, \& Koomen, H. M. Y. (2009). Widening the View on Teacher-Child Relationships: Teachers' Narratives Concerning Disruptive Versus Nondisruptive Children. School Psychology Review, 38(1), 86-101.

Spilt, J. L, \& Koomen, H. M. Y. (2009). Widening the View on Teacher-Child Relationships: Teachers' Narratives Concerning Disruptive Versus Nondisruptive Children. School Psychology Review, 38(1), 86-101.

The Curriculum Development Council (2008). Chinese Language Education Key Learning Areas Supplementary Guide to the Chinese Language Curriculum for Non-Chinese Speaking Students (English Translated Version). Hong Kong: Government Printing Division.

Valdés, G. (1998). The World Outside and Inside Schools: Language and Immigrant 


\section{$3^{\text {rd }}$ International Conference on Research in EDUCATION}

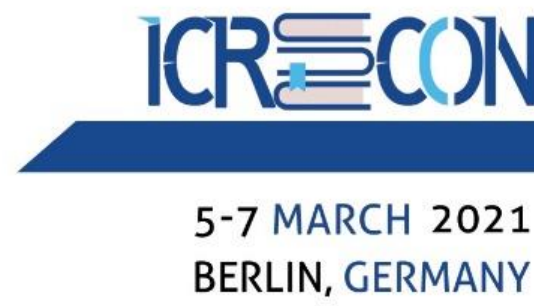

Children. Educational Researcher, 27(6), 4-18.

Verloop, N., Van Driel, J. \& Meijer, P. (2001). Teacher knowledge and the knowledge base of teaching. International Journal of Educational Research, 35(5), 441-461.

Weare, K. (2000). Promoting mental, emotional, and social health : A whole school approach. London; New York: Routledge.

Willis, S., Thompson, S., \& University of Missouri - Kansas City. (2003). The impact of the teacher/student relationship on African-American middle school students, in the context of classroom behavior [electronic resource].

Wubbles, T. \& Berkelmans, M. (2005). Two decades of research on teacher-student relationships in class . International Journal of Educational Research, 43 (1-2), 6-24.

Yamamoto, Y. \& Holloway, S. D. (2010). Parental Expectations and Children's Academic Performance in Sociocultural Context. Educational Psychology Review, 22(3), 189-214.

Yunus, M. M., Osman, W. S. \& Ishak, N. M. (2011). Teacher-student relationship factor affecting motivation and academic achievement in ESL classroom. Procedia-Social and Behavioral Sciences, 15 2637-2641.

Zaccor, K. M. (2018). Connecting With Students Through a Critical, Participatory Curriculum: An Exploration Into a High School History Teacher's Construction of Teacher-Student Relationships. Urban Education (Beverly Hills, Calif.), 4208591879477.

王俊菊 \& 朱耀云 (2010). 中国师生关系观的历史嬗变与现代审思. 当代教育科学, (19), 51-53.

叶子 \& 庞丽娟. (1999). 论儿童亲子关系、同伴关系和师生关系的相互关系. 心理发展与 教育, (4), 50-53.

林偉業 (2013). 以任務型學習策略, 從生活應用中學習中文. In 林偉業, 張慧明, 許守 仁 飛越困難 一起成功 教授非華語學生中文的良方 (pp. 60-67). 香港: 香港大學教 育學院中文教育研究中心.

張慧明 (2015). 從無助到互助. In 張慧明 \& 林偉業 從無助到互助 教授非華語小學生女 中文教師手冊 (pp. I-IX). 香港: 香港大學 教育學院 中文教育研究中心.

張慧明 (2018). 多元文化的力量. In 跨文化中文教學協作的力量 (pp. 1-8). 香港: 香港大 學 教育學院 中文教育研究中心.

張慧明, 黃綺玲 (2013). 利用資源, 創設多元中文學習經歷. In 林偉業, 張慧明, 許守 仁飛越困難一起成功 教授非華語學生中文的良方 (pp. 60-67). 香港: 香港大學教 育學院中文教育研究中心.

教育局 (2018). 學習宗旨、學校課程架構和規劃. 香港: 政府印務科.

教 育 局 (2019). Education Opportunities in Hong Kong. Retrieved from 


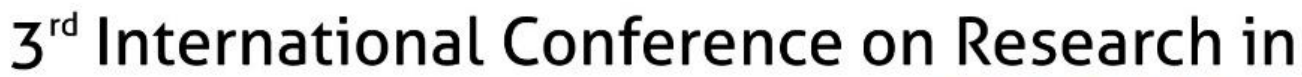 EDUCATION}

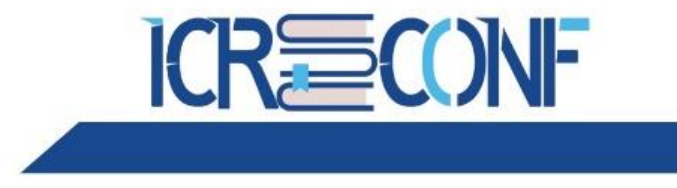

5-7 MARCH 2021 BERLIN, GERMANY

https://www.edb.gov.hk/attachment/en/student-parents/ncs-students/overview/Education \%200pportunities\%20in\%20HK_Oct_2019.pdf

教育局 (2019). 中國語文課程第二語言學習架構」配套資源. Retrieved from https://www.edb.gov.hk/attachment/tc/curriculum-development/kla/chi-edu/second-lang /NLF_brief_2019.pdf

葉重新 (2012). 教育研究法. 台北: 心理出版社.

謝錫金, 祁永華 \& 岑紹基 (2012). 非華語學生的中文學與教. 香港: 香港大學.

羅燕琴 (2016). 文言作品閱讀策略教學理論與實踐. In 羅燕琴 閱我深意文言作品學與教 的理論與實踐 (pp. 115-150). 香港: 香港大學出版社. 